\title{
Preparation and Characterization of Bio-based Activated Carbon from Fish Scales
}

\author{
Qingsong Ji, Haichao Li,* and Jingjing Zhang \\ The object of this study was to prepare activated carbons containing \\ nitrogenous functional groups by a chemical method from nitrogen- \\ containing raw materials. Fish (Ctenopharyngodon idellus) scales \\ were impregnated with phosphoric acid $\left(\mathrm{H}_{3} \mathrm{PO}_{4}\right)$ and activated at \\ varied temperatures. The adsorption ability, structural characteristics, \\ surface chemistry, and morphology of the activated carbons were \\ characterized by methylene blue and iodine values, nitrogen \\ adsorption, the Boehm method, scanning electron microscopy (SEM), \\ and X-ray photoelectron spectroscopy (XPS). The total alkaline groups \\ content of the activated carbon produced from fish scales was 0.4330 \\ $\mathrm{mmol} / \mathrm{g}$, the total acidic groups was $1.68 \mathrm{mmol} / \mathrm{g}$, the Brunauer- \\ Emmett-Teller (BET) surface area was $501 \mathrm{~cm}^{2} / \mathrm{g}$, and the total pore \\ volume was $0.284 \mathrm{~cm}^{3} / \mathrm{g}$. The average pore diameter was $1.94 \mathrm{~nm}$ \\ under an activation temperature of $550^{\circ} \mathrm{C}$, an activation time of $1 \mathrm{~h}$, \\ and an impregnation ratio of 2 . As a result of this study, nitrogenous \\ functional groups that contained acid-base amphoteric adsorbent were \\ produced.
}

Keywords: Activated carbon; Fish scales; $\mathrm{H}_{3} \mathrm{PO}_{4}$; Nitrogenous functional groups; Amphoteric adsorbent

Contact information: College of Chemistry and Chemical Engineering, Qinghai Nationalities University, Xining 810007, PR China; *Corresponding author: lihaichao@vip.163.com

\section{INTRODUCTION}

Activated carbons with developed pore structures and excellent chemical properties have played an important role in the fields of adsorption (Lorenc-Grabowska et al. 2013), catalysis (Bedia et al. 2009), and electrochemistry (Choi et al. 2013). In order to fulfill the needs of practical applications, there has been increased interest in activated carbon with better performance, especially for the preparation and surface modification of nitrogencontaining activated carbons (Xie et al. 2003; Li et al. 2019). Generally, the surface chemical properties of activated carbon are mainly determined by oxygenous and nitrogenous functional groups (Yao et al. 2014). Due to the presence of oxygenous functional groups (carboxyl and phenolic hydroxyl groups), the surface of activated carbon is acidic. Nitrogenous functional groups that contain activated carbons have both acidic and basic functional groups (amine groups) on the surface, so they exhibit amphoteric characteristics (Lahaye 1998; Mangun et al. 1999; Fuente et al. 2003).

The traditional activated carbons almost have no nitrogenous functional groups, which can be attributed to the fact that they are commonly based on wood and coal as raw materials, and these have extremely low nitrogen content. To obtain activated carbons with nitrogenous functional groups many methods of adding an external nitrogen source have been used. There are usually three methods for the preparation of amphoteric nitrogenous functional groups with activated carbons. One method is directly activating the nitrogencontaining material with an activator such as phosphoric acid $\left(\mathrm{H}_{3} \mathrm{PO}_{4}\right)($ Oginni et al. 2019). 
Lorenc-Grabowska et al. (2013) used nitric acid as an activator to treat the raw materials and perform a redox reaction. Palomo et al. (2017) used ammonia activation of raw materials at high temperature. Because the surface of the activated carbons contains different nitrogenous functional groups, its physical and chemical properties are optimized. All the activated carbon samples had different nitrogen contents ( $0.75 \mathrm{wt} \%$ to $42 \mathrm{wt} \%)$, so the surfaces of each sample had different basicities (Lorenc-Grabowska et al. 2013). Some researchers have shown that the presence of amide groups improves the adsorption and affinity of the carbon dioxide $\left(\mathrm{CO}_{2}\right)$ molecules (Pevida et al. 2008). In the field of electrochemistry, the presence of condensed nitrogen structures such as pyridine increases the capacitance, improves the charge transfer, and enhances the electrochemical reduction (Byrne et al. 2014).

In this work, fish (Ctenopharyngodon idellus) scales, a nitrogen-containing biomass, were used as raw materials, and it was indicated that carbon materials with nitrogenous functional groups would be produced by traditional methods. Fish scales are rich in protein and minerals, and they are mainly composed of protein and hydroxyapatite (Dai et al. 2018). In the fish scales, the contents of protein and ash were $70 \%$ and $30 \%$, respectively. The proteins are mainly collagen and keratin. A small amount of globulin is also present. The ash is mainly hydroxyapatite and it contains a small amount of inorganic salts such as calcium carbonate, magnesium phosphate, and sodium phosphate (Liu et al. 2009). As the world depletes the supply of non-renewable resources, different raw materials must be sourced. China is the only country in the world where aquaculture exceeds fishing, and a large amount of waste such as fish scales are generated during processing. It is estimated that China's annual fish scale waste can reach $30 \times 10^{4} \mathrm{t}$ (Dai et al. 2018). Fish scales were used in this work to prepare activated carbon, which is a good way to utilize waste resources and transform fish scales into high value-added activated carbon products.

\section{EXPERIMENTAL}

\section{Preparation of the Activated Carbon Samples}

The activated carbon samples were prepared via chemical activation, by using fish (C. idellus) scales as the precursor. First, the fish scales were boiled in water for a $0.5 \mathrm{~h}$, rinsed repeatedly with water to remove the impurities, and dried. Ten grams of fish scales were impregnated with $85 \% \mathrm{H}_{3} \mathrm{PO}_{4}(\mathrm{w} / \mathrm{w})$ aqueous solution for $12 \mathrm{~h}$ at room temperature, and dried. The impregnation ratio value $\left(\mathrm{H}_{3} \mathrm{PO}_{4} /\right.$ fish scales mass ratio) was 2 . Once the fish scales were impregnated and dried, they were placed in a muffle furnace at $550{ }^{\circ} \mathrm{C}$ for $1 \mathrm{~h}$ (Rosas et al. 2010). The obtained sample was washed with distilled water at a constant $\mathrm{pH}$ until elution was reached. The sample was then dried for $24 \mathrm{~h}$ (Palomo et al. 2017).

\section{Morphology}

The morphologies of the activated carbon specimens produced from fish scales were characterized using a Hitachi SU8010 scanning electron microscopy (SEM) (Tokyo, Japan). Double-sided adhesive tape was used to fix the activated carbon sample to the specimen stub. The carbon sample was transferred into the vacuum chamber, where the microscope scanned the sample with an electron beam (Oginni et al. 2019). Using the instrument software, the micrographs were obtained at a high voltage of $20 \mathrm{kV}$, the scanning internal was $15 \mathrm{~mm}$, and the acquisition time was $100 \mathrm{~s}$. 


\section{Surface Area and Pore Size Distribution}

The nitrogen adsorption/desorption isotherms of the activated carbons were performed at $77.35 \mathrm{~K}$. The Brunauer-Emmett-Teller (BET) method was used to calculate the surface area. The total pore volume was calculated using $\mathrm{N}_{2}$ adsorption and the microspore volume was calculated by t-plot model. The pore size distributions of the sample were calculated by the Barret-Joyner-Halenda (BJH) model.

\section{Elemental Composition and Surface Chemistry}

The surface functional groups were analyzed by means of X-ray photoelectron spectroscopy (XPS), using the Boehm method. The XPS analyses of the samples were tested by a Kratos Analytical Ultra model X-ray photoelectron spectrometer (Spring Valley, NY, USA). The X-ray radiation source was $\mathrm{Mg} \mathrm{K \alpha}(1253.6 \mathrm{eV})$ at $12 \mathrm{KV}$. For the analysis of the XPS peaks, the maximum of the $\mathrm{C} 1 \mathrm{~s}$ peak was set at $284.6 \mathrm{eV}$ and used as reference for the other peaks (Bedia et al. 2011).

The Boehm titration method was used to determine the contents of the acidic and basic groups on the surface of the activated carbon. First, $0.05 \mathrm{~mol} / \mathrm{L} \mathrm{NaOH}, \mathrm{Na}_{2} \mathrm{CO}_{3}$, and $\mathrm{NaHCO}_{3}$ standard solutions were configured, $2 \mathrm{~g}$ of activated carbon sample into a conical triangular flask of $100 \mathrm{~mL}$ volume. Then $25 \mathrm{~mL}$ of standard lye was added into the flask. After stirring for $24 \mathrm{~h}$, the solids were filtered and washed with distilled water. Using methyl red as the end point indicator, the unreacted lye in the filtrate was titrated with the $0.05 \mathrm{~mol} / \mathrm{L} \mathrm{HCl}$ to the end point. The content of the corresponding groups was calculated according to the amount of alkali solution and $\mathrm{HCl}$ that was used (Boehm et al. 2002).

\section{RESULTS AND DISCUSSION}

The SEM images of the activated carbon produced from fish scales are shown in Fig. 1. As shown in Fig. 1a, all the activated carbons had a flaky structure, scattered randomly.

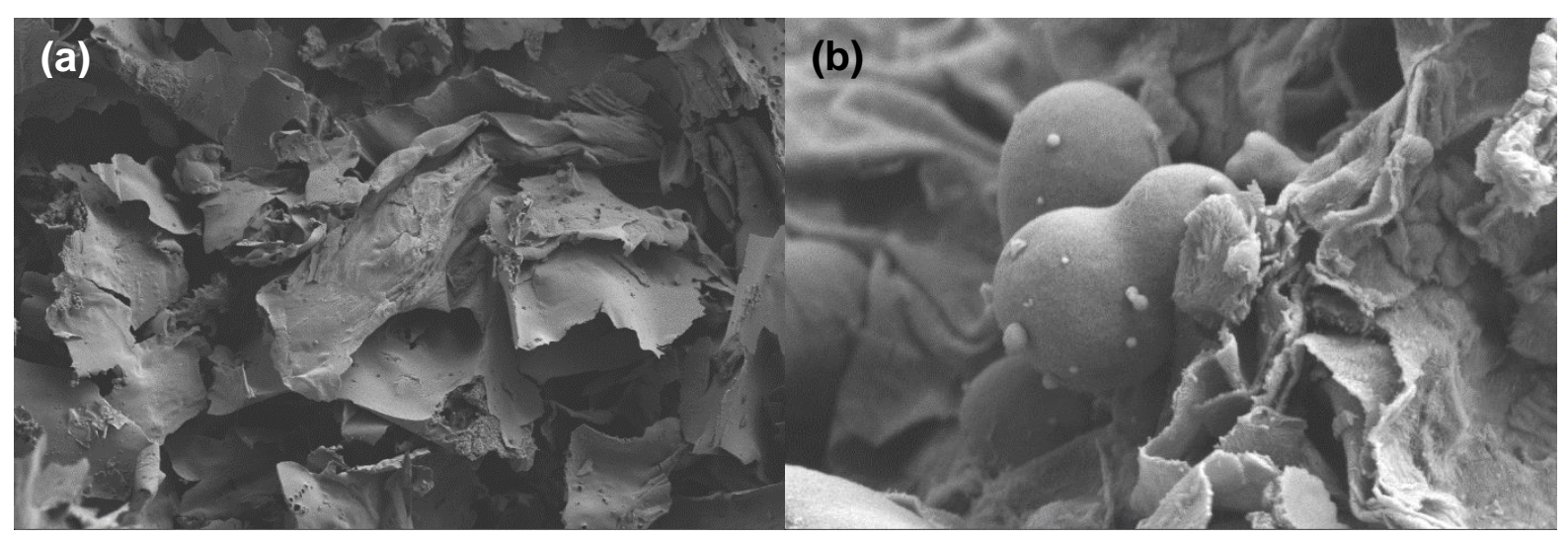

Fig. 1. SEM images of the activated carbons produced from grass carp scales at a a) $10 \mu \mathrm{m}$ scale and a b) $200 \mathrm{~nm}$ scale

The surface was relatively smooth and flat, and there were some holes, which is an indication that the original structural characteristics of the fish scales were retained after activation by $\mathrm{H}_{3} \mathrm{PO}_{4}$. Figure $1 \mathrm{~b}$ shows that the exterior surface of the activated carbons had certain granular materials. 
The adsorption amount of iodine and methylene blue to the activated carbons are shown in Table 1. As the temperature of preparation was increased, the adsorption amount of the activated carbons to iodine and methylene blue tended to increase and then decreased. The optimal adsorption capacity was observed at $550{ }^{\circ} \mathrm{C}$. It can be seen from the adsorption of the iodine that the activated carbon developed a microporous structure. The adsorption of the methylene blue indicated that the activated carbon had an appreciable content of mesopores.

Table 1. Properties of the Activated Carbon Produced from Fish Scales under Different Conditions

\begin{tabular}{|c|c|c|}
\hline Temp $\left({ }^{\circ} \mathrm{C}\right)$ & $\begin{array}{c}\text { Iodine Adsorption Value } \\
(\mathrm{mg} / \mathrm{g})\end{array}$ & $\begin{array}{c}\text { Methylene Blue Decolorization } \\
(\mathrm{mg} / \mathrm{g})\end{array}$ \\
\hline 400 & 350.35 & 91.50 \\
\hline 450 & 344.98 & 104.00 \\
\hline 500 & 481.16 & 150.00 \\
\hline 550 & 936.46 & 213.00 \\
\hline 600 & 716.58 & 170.50 \\
\hline 650 & 511.37 & 148.00 \\
\hline
\end{tabular}

Table 2. BET Surface Area Parameters of the Activated Carbon Produced from Fish Scales

\begin{tabular}{|c|c|c|c|}
\hline & $\begin{array}{c}\text { BET Surface Area } \\
\left(\mathrm{m}^{2} / \mathrm{g}\right)\end{array}$ & $\begin{array}{c}\text { Pore Volume } \\
\left(\mathrm{cm}^{3} / \mathrm{g}\right)\end{array}$ & $\begin{array}{c}\text { Average Pore } \\
\text { Diameter }(\mathrm{nm})\end{array}$ \\
\hline Fish Scales & 6.5633 & 0.0142 & 6.6484 \\
\hline Microporous & 427.565 & 0.1844 & - \\
\hline Mesoporous & 30.5325 & 0.0533 & 1.9364 \\
\hline Total & 501.356 & 0.2836 & \\
\hline
\end{tabular}

Figure 2 depicts the $\mathrm{N}_{2}$ adsorption-desorption isotherms at $77.35 \mathrm{~K}$ for the activated carbons that were prepared in this work. The BET surface areas of the activated carbons were assessed by the isotherms. The isotherm for the activated carbon can be classified as type IV in the entire relative pressure range, which indicates a highly porous structure, with microporous and mesoporous characteristics. The activated carbons produced from fish scales adsorbed more nitrogen in the initial part of the isotherm. It is also indicated that the activated carbons contained many microporous structures. When the relative pressure was in the range of 0.4 to 0.8 , the upward trend of the adsorption capacity slowed down. The $\mathrm{N}_{2}$ adsorption-desorption isotherms show a hysteresis loop, which is associated with capillary condensation that takes place in the mesoporous. This indicated that there were almost no large pore structures in activated carbons (Kumagai et al. 2010) 


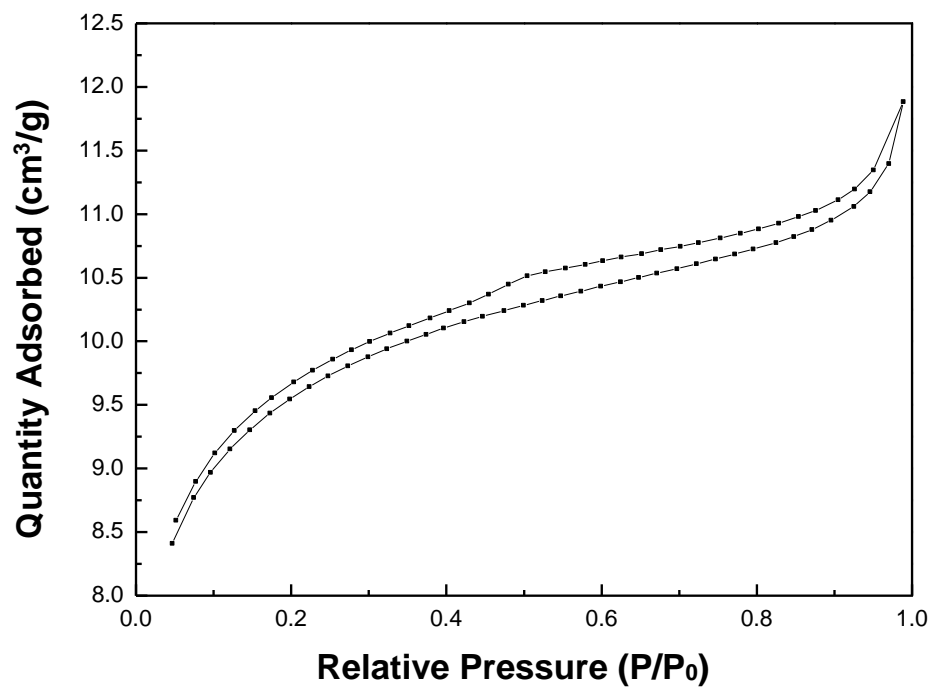

Fig. 2. The $\mathrm{N}_{2}$ adsorption-desorption isotherms at $77.35 \mathrm{~K}$

The pore size distribution is an intrinsic property of the activated carbon, which influences its adsorption performance (Oginni et al. 2019). The surface areas of the activated carbon produced from the fish scales was $501 \mathrm{~m}^{2} / \mathrm{g}$, the total pore volume was $0.244 \mathrm{~cm}^{3} / \mathrm{g}$, and the average pore size was $1.94 \mathrm{~nm}$ (Table 2). The surface area and the pore volume were the most influential characteristics of the microporous structure, which indicates that the activated carbon had a developed pore structure, a large surface area, and a large pore volume. This is conducive to the physical adsorption capacity of the activated carbon. Compared with wood waste activated by $\mathrm{H}_{3} \mathrm{PO}_{4}$ (with a surface area of more than $1000 \mathrm{~m}^{2} / \mathrm{g}$, a pore volume of more than $0.56 \mathrm{~cm}^{3} / \mathrm{g}$, an average pore size of more than 1.9 $\mathrm{nm})$, the surface area and total pore volume of fish scales activated carbon are lower, and the average pore size are similar (Mohammed et al. 2018). These findings imply that $\mathrm{H}_{3} \mathrm{PO}_{4}$ is also an effective activator for activation of fish scale.

Table 3. Contents of the Functional Groups

\begin{tabular}{|l|l|l|l|l|l|l|}
\hline $\begin{array}{l}\text { Temp } \\
\left({ }^{\circ} \mathrm{C}\right)\end{array}$ & 400 & 450 & 500 & 550 & 600 & 650 \\
\hline $\begin{array}{l}\text { Acidity } \\
\text { mmol/g }\end{array}$ & 2.1304 & 1.7043 & 1.2764 & 1.7166 & 1.3923 & 1.1291 \\
\hline $\begin{array}{l}\text { Basicity } \\
\text { mmol/g }\end{array}$ & 0.4181 & 0.3162 & 0.3034 & 0.4587 & 0.4056 & 0.3458 \\
\hline
\end{tabular}

The contents of the surface functional groups of the activated carbons are shown in Table 3. By using different temperatures of activation, it was possible to produce a string of similar functional groups. As the temperature was increased from $400{ }^{\circ} \mathrm{C}$ to $550{ }^{\circ} \mathrm{C}$, the basicity of the activated carbons increased from 0.418 to $0.459 \mathrm{mmol} / \mathrm{g}$. As the temperature was increased from $550{ }^{\circ} \mathrm{C}$ to $650{ }^{\circ} \mathrm{C}$, the basicity decreased from 0.459 to $0.346 \mathrm{mmol} / \mathrm{g}$. The changes in the amount of acidic functional groups are consistent with the changes in the basic functional groups. The results showed that oxygenous acidic functional groups and nitrogenous basic functional groups such as amines may be present in activated carbons produced from fish scales. 
The surface element distribution and the surface nitrogenous functional groups of the activated carbons were further analyzed by XPS. Four obvious peaks emerged in the samples around 133.1, 284.6, 400.1, and 532.1 eV, corresponding to P2p, C1s, N1s, and $\mathrm{O} 1 \mathrm{~s}$, respectively. The $\mathrm{C} 1 \mathrm{~s}, \mathrm{~N} 1 \mathrm{~s}$, and $\mathrm{P} 2 \mathrm{p}$ spectra for the activated carbons were deconvoluted, as shown in Fig. 3. To conduct an in-depth analysis, the C1s spectra consisted of a major graphitic carbon peak at a mean binding energy of $284.6 \mathrm{eV}$ and three types of carbon atoms were linked to oxygen and nitrogen. Peak 1 (284.6) consisted of C$\mathrm{C} / \mathrm{C}=\mathrm{C}$ bonds, peak $2(285.7 \mathrm{eV})$ consisted of phenolic, alcohol, ether, or $\mathrm{C}=\mathrm{N}$ groups, and peak $3(287.5 \mathrm{eV})$ consisted of $\mathrm{C}=\mathrm{O}$ or $\mathrm{C}-\mathrm{N}$ bonds (Biniak et al. 1997). This was according to data from the N1s spectra, which was inferred from the corresponding functional groups at peak 1 (399.8 eV)-N-pyridonic (N-5) (Lorenc-Grabowska et al. 2013). This shows that the nitrogen atoms are well preserved after treatment. The P2p spectra shows one type of phosphorus atom: peak 1 (133.5 eV)-phosphate and pyrophosphate (Oginni et al. 2019). The result suggested that $\mathrm{P}$ atom was successfully deposited in the activated carbon samples.
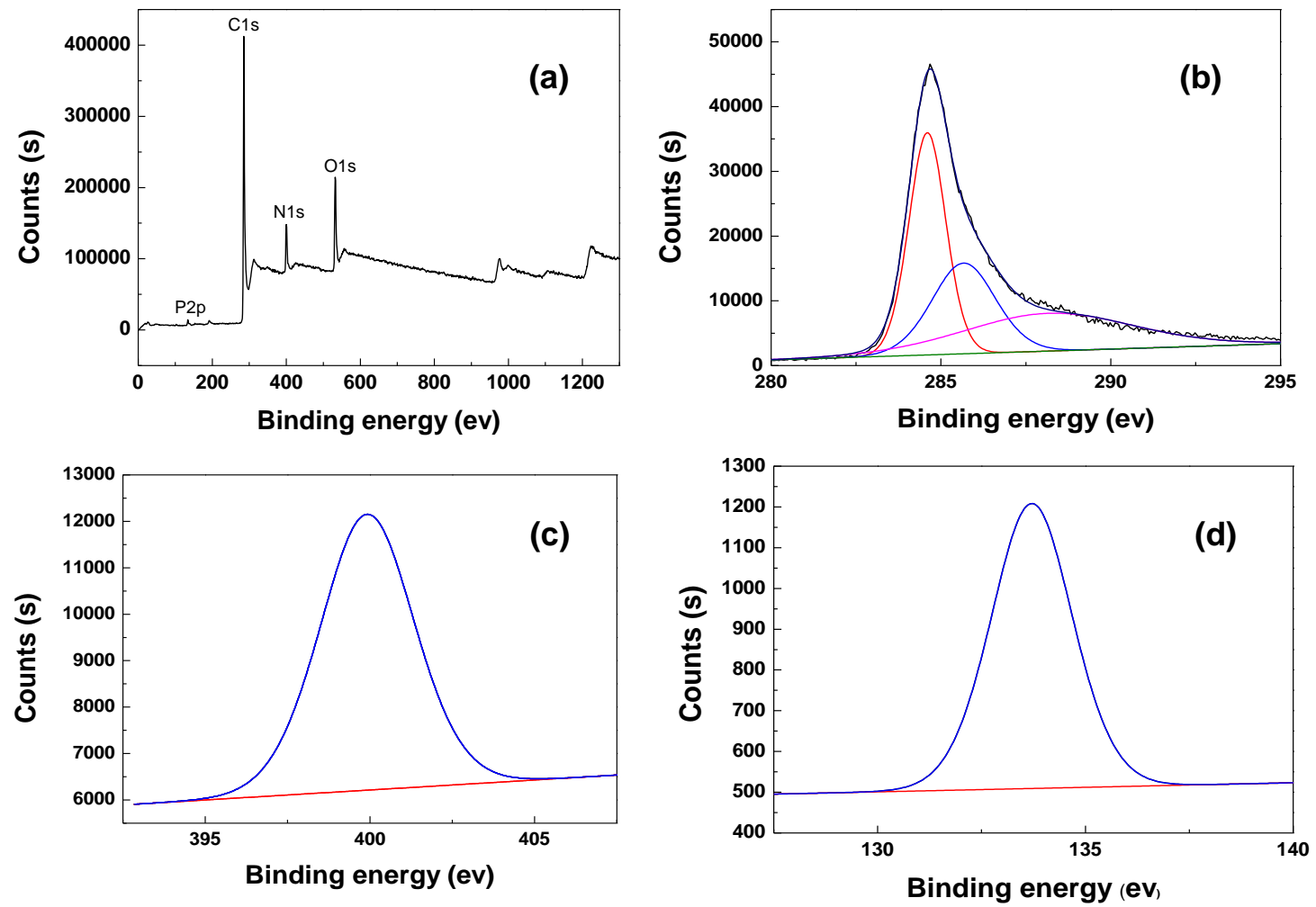

Fig3. The XPS images of the activated samples from the a) XPS survey, the b) C1s peak, the c) N1s peak, and the d) P2p peak

\section{CONCLUSIONS}

1. In this paper, porous nitrogenous activated carbons were successfully obtained via activating fish scales with $\mathrm{H}_{3} \mathrm{PO}_{4}$. The adsorption value of the methylene blue was 213 $\mathrm{mg} / \mathrm{g}$, and the adsorption value of the iodine was $936 \mathrm{mg} / \mathrm{g}$. The samples exhibited an ultrahigh specific surface area of $501 \mathrm{~cm}^{2} / \mathrm{g}$. The total pore volume was $0.284 \mathrm{cc} / \mathrm{g}$, the average pore diameter was $1.94 \mathrm{~nm}$, and the microporous ratio was $85.3 \%$. 
2. The series characterization of the activated carbon samples produced from fish scales showed that the surface of the activated carbon had abundant functional groups. The basicity and acidity of the activated carbon prepared are 0.459 and $1.717 \mathrm{mmol} / \mathrm{g}$, respectively. Phenolic, alcohol, ether, N-pyridonic, phosphate, and pyrophosphate functional groups were present in the activated carbon. These results showed that nitrogenous functional groups carbon materials can be produced by traditional methods which dealt with nitrogen-contained raw materials.

3. Activated carbon produced from fish scales was found to have a developed pore structure, large surface areas, and excellent adsorption performance. These characteristics provide this activated carbon with huge potential applications in the adsorption, catalysis, and electrochemical fields.

\section{ACKNOWLEDGMENTS}

Financial support was from the Natural Science Foundation of Qinghai province, China (Grant No. 2019-ZJ-928).

\section{REFERENCES CITED}

Bedia, J., Barrionuevo, R., Rodríguez-Mirasol, J., and Cordero, T. (2011). "Ethanol dehydration to ethylene on acid carbon catalysts," Applied Catalysis B: Environmental 103(3-4), 302-310. DOI: 10.1016/j.apcatb.2011.01.032

Bedia, J., Rosas, J. M., Márquez, J., Rodríguez-Mirasol, J., and Cordero, T. (2009). "Preparation and characterization of carbon based acid catalysts for the dehydration of 2-propanol," Carbon 47(1), 286-294. DOI: 10.1016/j.carbon.2008.10.008

Biniak, K., Szymański, J., Siedlewski, J., and Świątkowski, A. (1997). “The characterization of activated carbons with oxygen and nitrogen surface groups," Carbon 35(12), 1799-1810. DOI: 10.1016/S0008-6223(97)00096-1

Boehm, H. P. (2002). "Surface oxides on carbon and their analysis: A critical assessment," Carbon 40, 145-149. DOI: 10.1016/S0008-6223(01)00165-8

Byrne, T. M., Gu, X., Hou, P., Cannon, F. S., Brown, N. R., and Nieto-Delgado, C. (2014). "Quaternary nitrogen activated carbons for removal of perchlorate with electrochemical regeneration," Carbon 73, 1-12. DOI: 10.1016/j.carbon.2014.02.020

Choi, C. H., Park, S. H., Chung, M. W., and Woo, S. I. (2013). "Easy and controlled synthesis of nitrogen-doped carbon," Carbon 55, 98-107. DOI: 10.1016/j.carbon.2012.12.014

Dai, X., Liu, Y., and Chen, L. (2018). "Research process in comprehensive utilization of freshwater fish scales," Agricultural Products Processing 16, 61-66. DOI: 10.16693/j.cnki.1671-9646(X).2018.08.047

Fuente, E., Menéndez, J. A., Díez, M. A., Suárez, D., and Montes-Morán, M. A. (2003). "Infrared spectroscopy of carbon materials: A quantum chemical study of model compounds," Journal of Physical Chemistry B 107(26), 6350-6359. DOI: 10.1021/jp027482g

Kumagai, S., Ishizawa, H., and Toida, Y. (2010). "Influence of solvent type on dibenzothiophene adsorption on to activated carbon fiber and granular coconut shell activated carbon," Fuel 89(2), 365-371. DOI: 10.1016/j.fuel.2009.08.013 
Lahaye, J. (1998). "The chemistry of carbon surfaces," Fuel 77(6), 543-547. DOI: 10.1016/S0016-2361(97)00099-9

Li, L. Y., Gong, X. D., and Abida, O. (2019). "Waste-to-resources: Exploratory surface modification of sludge-based activated carbon by nitric acid for heavy metal adsorption," Waste Management 87, 375-386. DOI: 10.1016/j.wasman.2019.02.019

Liu, Y., Liu, Z.-w., Tang, J.-m., and Wu, S.-w. (2009). "Preparation of hydrolysis collagen from freshwater scale by enzymatic hydrolysis," Food Research and Development 6, 99-103.

Lorenc-Grabowska, E., Gryglewicz, G., and Diez, M. A. (2013). "Kinetics and equilibrium study of phenol adsorption on nitrogen-enriched activated carbons," Fuel 114, 235-243. DOI: 10.1016/j.fuel.2012.11.056

Mangun, C. L., Benak, K. R., Daley, M. A., and Economy, J. (1999). "Oxidation of activated carbon fibers: Effect on pore size, surface chemistry, and adsorption properties," Chemistry of Materials 11(12), 3476-3483. DOI: 10.1021/CM990123M

Mohammed, D., Tanweer A., Rokiah, H., Norafizah, S., Mohammad, N. A., Junita M. S. and Othman, S. (2018). "Comparison of surface properties of wood biomass activated carbons and their application against rhodamine B and methylene blue dye," Surfaces and Interfaces 11, 1-13. DOI: 10.1016/j.surfin.2018.02.001

Oginni, O., Singh, K., Oporto, G., Dawson-Andoh, B., McDonald, L., and Sabolsky, E. (2019). "Effect of one-step and two-step $\mathrm{H}_{3} \mathrm{PO}_{4}$ activation on activated carbon characteristics," Bioresource Technology Reports 8, 100307. DOI: 10.1016/j.biteb.2019.100307

Palomo, J., Ternero-Hidalgo, J. J., Rosas, J. M., Rodríguez-Mirasol, J., and Cordero, T. (2017). "Selective nitrogen functionalization of phosphorus-containing activated carbons," Fuel Processing Technology 156, 438-445. DOI: 10.1016/j.fuproc.2016.10.006

Pevida, C., Plaza, M. G., Arias, B., Fermoso, J., Rubiera, F., and Pis, J. J. (2008). "Surface modification of activated carbons for $\mathrm{CO}_{2}$ capture," Applied Surface Science 254(22), 7165-7172. DOI: 10.1016/j.apsusc.2008.05.239

Rosas, J. M., Bedia, J., Rodriguez-Mirasol, J., and Cordero, T. (2010). "On the preparation and characterization of chars and activated carbons from orange skin," Fuel Processing Technology 91(10), 1345-1354. DOI: 10.1016/j.fuproc.2010.05.006

Xie, Q., Zhang, X.-1., Chen, Q.-r., and Gong, G.-z. (2003). "Influence of surface modification by nitric acid on the dispersion of copper nitrate in activated carbon," New Carbon Materials 18(3), 203-208.

Yao, J.-J., Chen, S.-L., Kong, H.-H., Xiao, J., and Liu, Z.-L. (2014). “Effects of porosity property and acid functional groups of activated carbons on adsorption of three flavors," Modern Food Science and Technology 30(2), 72-77.

Article submitted: October 13, 2020; Peer review completed: November 15, 2020; Revised version received and accepted: November 24, 2020; Published: November 30, 2020.

DOI: 10.15376/biores.16.1.614-621 